DOI https://doi.org/10.30525/978-9934-588-81-5-2.56

\title{
USE OF SYNTHROPY INDEX IN PREVENTIVE MEDICINE
}

\author{
Peresypkina T. V. \\ PhD, Assistant Professor, \\ Head of the Department of the Scientific Organization of Medical Care \\ to Schoolchildren and Adolescents \\ State Institution «Institute for Children and Adolescents Health Care \\ at the National Academy of Medical Sciences of Ukraine»

\section{Merkulova T. V.} \\ $P h D$,
}

Head of the Department of Hygiene of School-Age Children and Adolescents

State Institution «Institute for Children and Adolescents Health Care

at the National Academy of Medical Sciences of Ukraine»,

Associate Professor at the Department of Basic

and General Scientific Studies

Kharkiv International Medical University

Butenko A. I.

$P h D$,

Deputy Chief Physician for Clinical Work

State Institution "Institute for Children and Adolescents Health Care at the National Academy of Medical Sciences of Ukraine»,

Associate Professor at the Department of Pediatrics № 2

of the Medical Faculty

\section{N. Karazin Kharkiv Nation University}

\section{Peresypkina Anna}

Assistant at the Department of Pediatrics № 2 of the Medical Faculty,

V. N. Karazin Kharkiv National University

\section{Holubnicha Halina}

Assistant at the Hygiene and social medicine Department

of the Medical Faculty

V. N. Karazin Kharkiv National University

Kharkiv, Ukraine

According to literature sources, in the world there is a tendency that non-communicable diseases are increasing among the entire population, including children. The loss of health among children is becoming a problem today, because only $10-15 \%$ of senior pupils remain healthy by the 
time they leave school $[1,2]$. This situation requires the urgent measures of prevention of non-communicable diseases, especially through strengthening of preventive work among schoolchildren.

Preventive measures increase their effectiveness if they are based on an analysis of health status in terms of age or gender and are developed for specific groups or social conditions. The prevalence of diseases among adolescent children in Ukraine is 2177.7\% 0 (per 1000 in 2017), which suggests the presence of several diseases in one teenager [3]. The tendency of the combination of diseases is also confirmed by the data of the assessment of pathological affection based on the results of the medical examinations of schoolchildren.

One of the methods for determining the association of diseases is the method for calculating the syntropy index, which was proposed by M. Pfoundler and L. von Zecht. Syntropy is the mutual tendency of two desiases or pathological conditions to manifest together [4].

In medicine This method is used to assess multiple malformations in order to determine the frequency of certain types of combined pathology; is used to identify common genes in development of bronchial asthma and other allergic diseases; in determining the pathogenesis of associated diseases of the digestive system and bronchial system in order to optimize the examination and processes of treatment.

To establish the variants of combined, syntropic diseases among school-age children, an analysis of the data of deep medical examinations of 216 schoolchildren was carried out, medical examination took place every year during the period of their education from grades 1 to 9. The most frequent pathology in terms of age and sex was determined and the syntropy indices for nosological forms were calculated.

Thus, according to our data, it has been established that among girls, the morpho-functional deviation that forms syntropic groups (multiple connections) during the period of study from the first to the fifth grade is functional disorders of gallbladder, which is most often a syntropic «marker» pathology for such deviations as hypertrophy of the palatine tonsils, neurasthenia, postural disorders or functional weakness of the feet. In the period of the fifth - eighth classes pathologies with the greatest combination for girls are disorders of the neurological sphere (neurasthenia, cerebrospinal fluid-hypertensive syndrome, vegetative-vascular dystonia), which was combined with chronic tonsillitis, myopia, functional disorders of gallbladder and postural disorder. In the ninth grade, diffuse goiter of grade I among girls has a high degree of syntropia with vegetative-vascular dysto- 
nia, functional disorders of gallbladder, myopia and postural disorders or functional weakness of the feet.

Among boys there were less syntropic groups of morpho-functional disorders than among girls. «Marker» disorders (nosological forms with a high frequency of syntropic connections) often are disorders of the nervous system. So, neurasthenia is combined with behavioral disorders, functional disorders of gallbladder, postural disorders, myopia. Thus, knowing the probability of occurrence of the combined diseases - types of syntropias in different age periods it makes possible creation of an algorithm for rational diagnostic, and sequently preventive measures.

\section{References:}

1. Стан здоров'я дитячого населення - майбутнє країни (частина 1). Антипкін Ю.Г., Волосовець О.П., Майданник В.Г. та інш. Здоровье ребенка. Том 13, №1, 2018, C. 5-13. doi: http://dx.doi.org/10.22141/22240551.13.1.2018.127059

2. Стан здоров'я дитячого населення - майбутнє країни (частина 2). Антипкін Ю.Г., Волосовець О.П., Майданник В.Г. та інш. Здоровье ребенка. Том 13, № 2, 2018, С. 5-14. doi: http://dx.doi.org/10.22141/2224-0551.13.2.2018.129546

3. Центр медичної статистики MO3 України. URL: https://moz.gov.ua/article/statistic/centr-medichnoi-statistiki-moz-ukraini

4. M. Pfoundler, L. von Zecht. Biologische all geme in probleme der medizine. Konstitution, diathese, disposition. Springer. Berlin. 1947. P. 318 . 